\title{
Perceived Ease Of Use (Peou) And Ranking Of Payment Systems In Nigeria: Case For Systems Cannibalization
}

\author{
Clement Ikenna Okeke $(\mathrm{PhD})$ \\ Associate Professor, School of Management Sciences National Open University Of Nigeria, Lagos
}

\begin{abstract}
With a view to facilitating the cashless policy of Central Bank of Nigeria (CBN), the study ranked the three payment systems in Nigeria using the Perceived Ease of Use (PEOU) framework of Technology Acceptance Model (TAM). Based of ten factors of PEOU, 282 highly literate and financially active Nigerians who are aware of the three payment systems obtainable in Nigeria were required to rank them on a scale of 1-3. Analysis of the ranking showed that on the aggregate, e-payment system ranked first on the basis of PEOU factors, while in specific terms, cash payment system ranked first on the crucial factors of ease of use and clarity of operating payment systems, and cheque payment system ranked first on the factors of rigidity/inflexibility and ability to manipulate payment systems. For e-payment system to become the dominant payment system in Nigeria, the study recommended the Cannibalization of Cash and Cheque Payment Systems through the adoption of counter marketing strategies and the adoption of developmental marketing strategies for e-payment system.
\end{abstract}

Keywords: Cashless Policy, Counter Marketing Strategy, Payment Systems, Perceived Ease of Use, and Product Cannibalization.

\section{INTRODUCTION}

There are three payment systems with varying instruments in modern economies. These are cash, cheque and e-payment systems. All these payment systems and their varying instruments are available and in use in Nigeria. The ultimate goal of a payment system according to Ovia (2005) is to ensure that exchange of monetary value is achieved using payment instruments that offer the least risk, inconvenience and cost. An efficient payments system must be defined by a few attributes. It must be: reliable, prompt, accessible, secure, and cost effective [1]. A cursory look at the three types of payment systems will demonstrate that not all of them meet the critical requirements of least risk, inconvenience and cost. Not all of them also meet the criteria of reliability, promptness, accessibility, security, and cost effectiveness. Ovia (2005) had listed the major features and challenges plaguing cash and cheque payment systems. For cash the features are that (coins and notes) $80-$ $90 \%$ of transactions in Nigeria are carried out through this means and we presently have, N545.8 billion cash in circulation. For cheques large value transactions are usually cheque based [1].

Payment systems are expected not just to enable and facilitate exchange; increasingly they are playing more strategic roles in economic growth and development. The ultimate goal of a payment system according to Ovia (2005) is to ensure that exchange of monetary value is achieved using payment instruments that offer the least risk, inconvenience and cost. An efficient payments system must be defined by a few attributes. It must be: reliable, prompt, accessible, secure, and cost effective [1]. A cursory look at the three types of payment systems will demonstrate that not all of them meet the critical requirements of least risk, inconvenience and cost. Not all of them also meet the criteria of reliability, promptness, accessibility, security, and cost effectiveness. Ovia (2005) had listed the major features and challenges plaguing cash and cheque payment systems. For cash the features are that (coins and notes) $80-90 \%$ of transactions in Nigeria are carried out through this means and we presently have, N545.8 billion cash in circulation. For cheques large value transactions are usually cheque based. E-payment though with great promises, is relatively new and yet to be adopted and/or accepted and preferred by many Nigerians [1].

As observed by Financial Derivatives Company Limited (FDCL) (2012) an effective payment system is a vital part of the financial infrastructure of any economy. A well-functioning payment system is important to boost the efficiency of the financial system, improve consumer confidence and facilitate economic interactions and trade in both goods and services. By enabling commercial transactions to be completed faster, safer and cheaper, it would have a positive impact on economic growth and global competitiveness. The importance of an effective payment system is therefore reinforced by the established relationship between it and the level of economic activity and national development [2]. When the payment system is effective and efficient, it will translate to greater level of economic activity, higher level of consumer purchase and consumption, better revenue collection by governments and organizations, and indeed enhanced wellbeing of all economic actors and participants. The quest for improved payment system is therefore in the interest of all legitimate actors in the economic sphere [3]. 
While modern economies are shifting to e-payment system, Nigeria has remained predominantly a cash-based economy. In United States for instance, electronic funds transfers had six times the value of cheque payments [4]. As observed by Eze[5] although banking practice borrowed from the United Kingdom, is over a hundred years old, the other non-cash aspects of money have not taken root here. Mutual lack of trust makes many demand cash payments- and the recent disappointments in banking only made matters worse. What is expected is that Nigeria should leap rather than jump into the use of e-payment. It clearly holds promise to investors in the project, issuers, suppliers and customers alike [6]. This is consistent with the declared policy of Central Bank of Nigeria (CBN) to transit Nigeria from a cash-based to electronic-based economy, otherwise called cashless policy [7].

The central thrust of this study is to empirically determine the ranking of the three payment systems in Nigeria within the framework of Perceived Ease of Use (PEOU) deriving from Technology Acceptance Model (TAM). The ranking will reveal the perceptions of Nigerians on the three payment systems and recommend measures and strategies for getting them to accept and prefer e-payment system as the dominant payment system. The key question to be answered by the study is, what is the ranking of the three payment systems in Nigeria based on the experiences of users using PEOU framework?

The paper is organized in six sections. Section one is the introduction. In Section two relevant literature on Perceived Ease of Use and product cannibalization is reviewed. Section three discusses the methodology of data gathering and analysis. Section four presents the results and discussion of the study and section five presents the conclusion and recommendations of the study. Section six presents the limitations of the study and further research while section seven presents the references of the study.

\section{LITERATURE REVIEW}

\subsection{Technology Acceptance Model (TAM) and Perceived Ease of Use}

For the understanding of the basis for acceptance and use of payment systems the most advanced and widely used model is Technology Acceptance Model (TAM).To specially address the challenge of acceptance and use of technology Davis [8] and Davis et al.[9] proposed TAM to address why users accept or reject systems. The Technology Acceptance Model (TAM) has emerged as a powerful and parsimonious model that belongs to the information systems (IS) field.

TAM hypothesizes that a person's acceptance of a technology is determined by his/her voluntarily intentions to use that technology. The intention, in turn, is determined by the person's attitude toward the use of that technology and his/ her perception concerning its usefulness. Attitudes are formed from the beliefs a person holds about the use of the technology. The first dimensions of the attitude are PU and PEOU.

A key purpose of TAM is to provide a basis for tracing the impact of external variables on internal beliefs, attitudes, and intentions. It suggests that (PEOU), and (PU) are the two most important factors in explaining system use. Davis [8] defines PU as the degree to which a person believes that using a particular system would enhance his job performance and PEOU as the degree to which a person believes that using a particular system would be free from effort. PU is majorly measured by five independent factors, namely image, output quality, result demonstrability, voluntariness and job relevance.

For PEOU, Legris, Ingham and Collerette[10] proposed a four items measurement tool- learning to operate e-banking application is easy for me, I find it easy to get e-banking tools and facilities to do what I want to do, e-banking application is rigid and inflexible to interact with and overall, I find it easy to use e-banking applications in my financial transactions. For specific measures, PEOU is measured by the following:

- I Find it Cumbersome to Use E-Banking Tools and Processes;

- Learning to operate e-banking tools and processes was easy for me;

- Interacting with e-banking platforms is often frustrating;

- I find it easy to get e-banking platforms to do what I want to do;

- e-banking operation is rigid and inflexible to interact with;

- It is easy for me to remember how to perform tasks using e-banking application;

- Interacting with e-banking application requires a lot of mental effort;

- My interaction with e-banking is clear and unambiguous;

- I find it takes a lot of effort to become skillful in using e-banking facilities; and

- Over all, I find the application of e-banking operation easy to use.

Legris, ingham and collerette [10] concluded that TAM has proven to be a useful theoretical model in helping to understand and explain use behavior in information system implementation. It has been tested in many empirical researches and the tools used with the model have proven to be of quality and to yield statistically reliable results

Specifically, TAM has fully mediated the effects of system characteristics on use behavior. It predicts intention to use well. PU predicts intentions to use whereas PEOU is secondary and acts through PU [9]. 


\section{Product Cannibalization and Counter marketing Strategy}

Product cannibalization happens when an organisation grows by increasing the sales/usage of one product while reducing the usage/sales of another product of the same organisation. In marketing strategy, cannibalization refers to a reduction in sales volume, sales revenue, or market share of one product as a result of the introduction of a new product by the same producer[11]. Cannibalization can also be described as negative impact of a company's new product on the sales performance of its existing related products. Market cannibalization refers to a situation where a new product "eats" up the sales and demand of an existing product. This can negatively affect both the sales volume and market share of the existing product. Market cannibalization occurs when a new product intrudes on the existing market for the older product, rather than expanding the company's market base. Rather than appealing to a new segment of the market and increasing market share, the new product appeals to the company's current market, resulting in reduced sales and market share for the existing product. For example, when Apple introduced iPad, this took sales away from the original Macintosh, but ultimately led to an expanded market for consumer computing hardware [12].

Another example of cannibalization occurs when a retailer discounts a particular product. The tendency of consumers is to buy the discounted product rather than competing products with higher prices. When the promotion event is over and prices return to normal, however, the effect will tend to disappear. This temporary change in consumer behavior can be described as cannibalization, though scholars do not normally use the phrase "cannibalization" to denote such a phenomenon. In e-commerce, some companies intentionally cannibalize their retail sales through lower prices on their online product offerings. More consumers than usual may buy the discounted products, especially if they'd previously been anchored to the retail prices. Even though their in-store sales might decline, the company may see overall gains. Cannibalization is an important issue in marketing strategy when an organization aims to carry out brand extension. Normally, when a brand extension is carried out from one sub-category (e.g. Marlboro) to another sub-category (e.g. Marlboro Light), there is an eventuality of a part of the former's sales being taken away by the latter. However, if the strategic intent of such an extension is to capture a larger market of a different market segment notwithstanding the potential loss of sales in an existing segment, the move to launch the new product can be termed as "cannibalization strategy". In India, where the passenger-car segment is going up dramatically since the turn of this century, Maruti-Suzuki's launch of Suzuki Alto in the same sub-category as Maruti 800, which was the leader of the small-car segment to counter the competition from Hyundai is seen to be a classic case of cannibalization strategy [13].

According to Useem [14] Jack Welch refers to general electric's internet business unit as "destroyyour-business.com" while Andy Grove talks about a "valley of death "and Harvard Business School's Dr christensen calls the concept "survival by suicide". Changes in internet upstarts are threatening to overturn successful technologies and business models of the past. Remaining competitive in this rapidly evolving business environment may mean destroying the value of past investments-factories, relationships within a supply chain, or commitments to a certain way of doing things. It may mean actively working to depress share price and profitability, even if these actions may go against a managers training or beliefs. The internet is making cannibalization a common phenomenon. Counter marketing is the strategy adopted in destroying demand for the product that is to be cannibalized. Demand for such products is normally described as being unwholesome, hence requiring to be destroyed (i.e. reduced).

For CBN [7] and payment systems in Nigeria, the challenge of product cannibalization is in reducing the use of cash and cheque payment systems while increasing the use of e-payment platforms. In the extant case of CBN and payment systems, the three payment systems can be seen as substitute products of the same organization. While desiring to have the three payment systems coexisting side by side, it is the wish of CBN to have e-payment system as the dominant payment system for some strategic reasons. The circumstances of the three payment systems are dissimilar in some critical areas. While cash payment system is the oldest and most widely used payment system, it is facing the challenges of high cost of printing and administration and CBN has reasons to believe that a switch to e-payment system will better serve the interest of users and the national economy. Cheque payment is historically the second to cash payment system in Nigeria. It also has the benefit of many years of usage, familiarity and wide acceptance among Nigerian users. It nonetheless is facing some challenges in Nigeria presently and the cashless policy of CBN demands that its use be reduced so that epayment platforms will be accepted and become the dominant payment system in Nigeria.

Cannibalization of cash and cheque payment systems in favour of e-payment in Nigeria is particularly challenging because the three payment systems are being sold to the same market in the same locations. The central objective of cash and cheque payments system cannibalization is to reduce the use of cash and cheque payment systems while increasing the use of e-payment system platforms without reducing aggregate level of financial transactions in the economy, indeed, while growing the level and value of financial transactions. 


\section{Research Methodology}

The data need of this study is defined in two broad areas first is the articulation of core benefits of epayment from the perspective of enlightened users of the payment system. Second is the determination of the challenges associated with the payment system again from the perspective of its users.

For the ranking of payment systems, 10 factors drawn from the Perceived Ease of Use (PEOU) under the TAM framework [8] and [9] were listed for the respondents to use in ranking three payment systems on a scale of 1-3 based on the experiences of the respondents. The cumulative points for each of the factors was computed based on multiples of 3 for the first, 2 for the second, and 1 for the third. The aggregate cumulative point was used in ranking the payment systems from first to third. The ten factors used were:

1) I find it cumbersome to use the tools and processes

2) Learning to operate the tools and processes is easy for me

3) Interacting with the platforms/tools and processes is often frustrating

4) I find it easy to get the payment system platforms to do what I want to do

5) Operating the payment system is rigid and inflexible to interact with

6) It is easy for me to remember how to perform tasks using the payment system application

7) Interacting with the payment system application requires a lot of mental effort

8) My interaction with the payment system platform is clear and unambiguous

9) I Find It Takes A Lot Of Effort To Become Skillful In Using The Payment System

10) Over all, I find the application of the payment system operation easy to use.

The study relied on questionnaire as the survey instrument for collecting data on the ranking of PEOU of payment systems based on Nigerian experience of respondents. The questionnaire listed the factors and required respondents to rank them based on their personal experience of payment systems. It became imperative therefore to select respondents from a population of highly literate and financially active Nigerians who are aware of the three payment systems obtainable in Nigeria.

To meet the outlined requirements of the data collection source, the study used a population of students of Enugu State University of Technology (ESUT) Business School, located in Enugu, the capital of Enugu state in south east, Nigeria. Being an executive programme with students mostly working, drawn from all states, tribes and religions in Nigeria, the population surveyed met the requirement of financially well to do and active users of e- payment system in Nigeria. This is in line with the Grounded Theorists rule of selecting purposive samples from participants who represent the major categories of people relevant to the research [15] and [16].Being a lecturer on the ESUT programme facilitated access to the students and cooperation from them in completing the questionnaire. With a population of 600 students, the questionnaire was administered on all the students in MBA, MSc and PGD classes on the $14^{\text {th }}$ and $15^{\text {th }}$ of December, 2013. A total of 319 copies of the questionnaire were administered and retrieved within the two days. Given incompleteness' and inconsistency in completion 37 returned questionnaire were rejected. Thus, 282 returned questionnaires were analyzed. This gave an effective response rate of $88.40 \%$.

The collected primary data were presented on tables and analyzed using frequency distribution and aggregation of points to arrive at cumulative points and enable ranking. Data were also collected and analyzed to define the profile of respondents.

4.1 Profile of Respondents.

\section{Results And Discussion}

The profile of respondents is captured on Table 1 below.

Table 1: Profile of Respondents

\begin{tabular}{|l|l|}
\hline Category & Statistics \\
\hline Gender & \\
Male & $177(62.77 \%)$ \\
Female & $105(37.23 \%)$ \\
Age & \\
20-30 years & $42(14.89 \%)$ \\
30-40 years & $165(58.51 \%)$ \\
40-50 years & $45(15.96 \%)$ \\
$50-60$ years & $27(9.57 \%)$ \\
60 years and above & $03(1.06 \%)$ \\
Marital Status & \\
Single & $73(25.89 \%)$ \\
Married & $201(71.28 \%)$ \\
Divorced & $4(1.42 \%)$ \\
Widowed & $4(1.42 \%)$ \\
Gross Annual Income & \\
Less than N1m & $54(19.15 \%)$ \\
N1M-N3M & $111(39.36 \%)$ \\
N3M-N5M & $63(22.34 \%)$ \\
N5M-N7M & $27(9.58 \%)$ \\
N7M-N9M & $6(2.13 \%)$ \\
N9M- N11M & $3(1.06 \%)$ \\
N11M-N13M & $2(0.71 \%)$ \\
N13M and above & $1(0.36 \%)$ \\
\hline
\end{tabular}




\begin{tabular}{|l|l|}
\hline Employment Status & $267(94.68 \%)$ \\
Employed & $15(5.32 \%)$ \\
Unemployed & \\
Sector Of Employment & $119(42.20 \%)$ \\
Public & $163(57.80 \%)$ \\
Operation Of Account With Nigerian Banks & $282(100 \%)$ \\
Yes & $0(0 \%)$ \\
No & \\
Highest Educational Qualification & $177(62.77 \%)$ \\
HND/BSc & $33(11.70 \%)$ \\
PGD & $69(24.47 \%)$ \\
M.Sc/MBA/MPA & $03(1.06 \%)$. \\
\hline
\end{tabular}

Source: Field Survey, 2013.

The respondents are highly educated with $62.77 \%$ having a minimum educational qualification of first degree (BSc, BA and HND. Others hold higher educational qualifications.

The major age bracket of respondents was 30-40 years, accounting for $58.00 \%$, and the least, 60 years and above with $1.06 \%$.

$62.77 \%$ of respondents are male.

While $71.28 \%$ ) of the respondents are married, $25.89 \%$ are single and $1.42 \%$ are divorced.

The major income brackets of respondents were N1M-N3M (39.36\%) and N3M-N5M (22.34\%) per annum.

$94.68 \%$ of respondents are employed with $57.80 \%$ working in the public sector and $42.420 \%$ in the private sector.

5.0 $100 \%$ of the respondents have been involved with all payment system and maintain account with banks in Nigeria.

\subsection{Analysis of Data}

Table 2: Ranking of Perceived Ease of Use (PEOU) Of Cash, Cheque and E-Payment Systems

\begin{tabular}{|c|c|c|c|}
\hline FACTORS & $\mathrm{CASH}$ & CHEQUE & E-PAYMENT \\
\hline $\begin{array}{l}\text { I find it cumbersome to use the } \\
\text { tools and processes }\end{array}$ & $\begin{array}{l}\text { First- } 126(3)=378 \\
\text { Second-12(2)=24 } \\
\text { Third-144(1)=144 } \\
\text { Total }=546(\text { Third })\end{array}$ & $\begin{array}{l}\text { First }-15(3)=45 \\
\text { Second }-237(2)=474 \\
\text { Third- } 30(1)=30 \\
\text { Total }=549(\text { Second })\end{array}$ & $\begin{array}{l}\text { First- } 144(3)=432 \\
\text { Second-33(2)=66 } \\
\text { Third-105(1) }=105 \\
\text { Total }=603 \text { (First). }\end{array}$ \\
\hline $\begin{array}{l}\text { Learning to operate the tools and } \\
\text { processes is easy for me }\end{array}$ & $\begin{array}{l}\text { First-108(3)=324 } \\
\text { Second }-54(2)=108 \\
\text { Third-120(1)=120 } \\
\text { Total=552(Third) }\end{array}$ & $\begin{array}{l}\text { First }-36(3)=108 \\
\text { Second }-210(2)=420 \\
\text { Third-36(1) }=36 \\
\text { Total }=564(\text { Second })\end{array}$ & $\begin{array}{l}\text { First- } 138(3)=414 \\
\text { Second-21(2)=42 } \\
\text { Third-123(1) }=123 \\
\text { Total }=579 \text { (First). }\end{array}$ \\
\hline $\begin{array}{l}\text { Interacting with the } \\
\text { platforms/tools and processes is } \\
\text { often frustrating }\end{array}$ & $\begin{array}{l}\text { First- } 81(3)=243 \\
\text { Second-42(2)=84 } \\
\text { Third-109(1)=109 } \\
\text { Total }=436(\text { Third })\end{array}$ & $\begin{array}{l}\text { First }-39(3)=117 \\
\text { Second-204(2)=408 } \\
\text { Third-39(1)=39 } \\
\text { Total }=564(\text { Second })\end{array}$ & $\begin{array}{l}\text { First- } 162(3)=426 \\
\text { Second-33(2)=66 } \\
\text { Third- } 87(1)=87 \\
\text { Total }=579 \text { (First). }\end{array}$ \\
\hline $\begin{array}{l}\text { I find it easy to get the payment } \\
\text { system platforms to do what I } \\
\text { want to do }\end{array}$ & $\begin{array}{l}\text { First-123(3)=369 } \\
\text { Second-54(2)=108 } \\
\text { Third-105(1)=105 } \\
\text { Total }=582 \text { (Second) }\end{array}$ & $\begin{array}{l}\text { First }-192(3)=486 \\
\text { Second }-51(2)=102 \\
\text { Third-39(1)=39 } \\
\text { Total }=627 \text { (First) }\end{array}$ & $\begin{array}{l}\text { First }-36(3)=108 \\
\text { Second-117(2)=234 } \\
\text { Third-159(1)=159 } \\
\text { Total }=501 \text { (Third). }\end{array}$ \\
\hline $\begin{array}{l}\text { It is easy for me to remember } \\
\text { how to perform tasks using the } \\
\text { payment system application }\end{array}$ & $\begin{array}{l}\text { First-129 }(3)=387 \\
\text { Second- } 45(2)=90 \\
\text { Third-108(1)=108 } \\
\text { Total }=585 \text { (First) }\end{array}$ & $\begin{array}{l}\text { First }-30(3)=90 \\
\text { Second }-207(2)=414 \\
\text { Third- } 45(1)=45 \\
\text { Total }=549 \text { (Second) }\end{array}$ & $\begin{array}{l}\text { First-111(3)=333 } \\
\text { Second-27(2)=54 } \\
\text { Third-144(1) }=144 \\
\text { Total }=531(\text { Third }) \text {. }\end{array}$ \\
\hline $\begin{array}{l}\text { Interacting with the payment } \\
\text { system application requires a lot } \\
\text { of mental effort }\end{array}$ & $\begin{array}{l}\text { First }-87(3)=261 \\
\text { Second-33(2)=66 } \\
\text { Third-162(1)=162 } \\
\text { Total }=489 \text { (Third) }\end{array}$ & $\begin{array}{l}\text { First }-15(3)=45 \\
\text { Second }-228(2)=456 \\
\text { Third-39 }(1)=39 \\
\text { Total }=540(\text { Second })\end{array}$ & $\begin{array}{l}\text { First-186(\#)=558 } \\
\text { Second-18(2)=36 } \\
\text { Third-78(1)=78 } \\
\text { Total }=672 \text { (First). }\end{array}$ \\
\hline $\begin{array}{l}\text { My interaction with the payment } \\
\text { system platform is clear and } \\
\text { unambiguous }\end{array}$ & $\begin{array}{l}\text { First- } 153(3)=459 \\
\text { Second-48(2)=144 } \\
\text { Third-81(1)=81 } \\
\text { Total }=684 \text { (First) }\end{array}$ & $\begin{array}{l}\text { First }-24(3)=72 \\
\text { Second }-213(2)=426 \\
\text { Third- } 45(1)=45 \\
\text { Total }=543 \text { (Second) }\end{array}$ & $\begin{array}{l}\text { First- } 114(3)=342 \\
\text { Second-18(2)=36 } \\
\text { Third-150(1) }=150 \\
\text { Total }=528(\text { Third }) \text {. }\end{array}$ \\
\hline Total & 5368 & 5679 & 5892 \\
\hline
\end{tabular}


Source: Field Survey, 2013.

Table 2 revealed that in terms of cumbersomeness in using the tools and processes of payment systems, e-payment is first with (603 points), followed by cheque (549 points) and then cash (546 points).

On the factor of learning to operate the tools and processes being easy, e-payment came first with 579 points, followed by cheque with 564 points and cash with 552 points.

On the factor of frustration with Interacting with the platforms/tools and processes, e-payment was first with 579 points, followed by cheque with 564 points and cash with 436 points.

For the factor of finding it easy to get the payment system platforms to do what I want to do, cheque was first with 627 points, followed by cash with 582 points and e-payment with 501 points.

On the factor of Operating the payment system being rigid and inflexible to interact with, cheque came first with 624 points, followed by e-payment 609 points and cash with 450 points.

For being easy to remember how to perform tasks using the payment system application, cash came first with 585 points, followed by cheque with 549 points and e-payment with 531 points.

On interaction with the payment system application requiring a lot of mental effort, e-payment was first with 672 points, cheque second with 540 points and cash third with 489 points.

Considering interaction with the payment system platforms being clear and unambiguous, cash came first with 684 points, followed by cheque with 543 points and e-payment with 528 points.

On the factor of taking a lot of effort to become skillful in using the payment, e-payment scored highest with 678 points, followed by cheque with 594 points and cash with 435 points.

On the factor of finding the application of the payment system operation easy to use e-payment came first with (612 points), followed by cash (609 points) and cheque (525 points).

\section{Findings}

The major findings of the study are summarized below:

A) Based on PEOU, the three payment systems are ranked on the aggregate as e-payment first with 5892 points, followed by cheque with 5679 points and cash with 5368 points. This ranking should be interpreted with caution: some of the factors are positive while others are negative. It will be more helpful to disaggregate the data to be able to arrive at conclusive findings.

B) In ranking Perceived Ease Of Use (PEOU) of payment systems, e-payment ranked first in the following factors:

- It takes a lot of effort to become skillful in using the payment system (678 points).

- Interacting with the payment system application requires a lot of mental effort (672 points).

- I find the application of the payment system operation easy to use (612 points).

- I find it cumbersome to use the tools and processes (603 points).

- Learning to operate the tools and processes is easy for me (579 points).

- Interacting with the platforms/tools and processes is often frustrating (579 points).

The factors in which e-payment ranked highest is mostly the ones on the difficulty and complexity of operating payment systems.

C) In ranking Perceived Ease Of Use (PEOU) of payment systems, cash payment system ranked first in the following factors:

- My interaction with the payment system platform is clear and unambiguous (684 points).

- It is easy for me to remember how to perform tasks using the payment system application (585 points).

Cash payment system ranked highest on the factors of ease and clarity of operating payment systems.

D) In ranking Perceived Ease Of Use (PEOU) of payment systems, cheque payment system ranked first in the following factors:

$\checkmark \quad$ I find it easy to get the payment system platforms to do what I want to do (627 points).

$\checkmark$ Operating the payment system is rigid and inflexible to interact with (624 points).

Cheque system ranked highest on the factors of rigidity and ease of manipulating payment systems.

\subsection{Conclusion}

\section{V. conclusion and recommendations}

On the aggregate, e-payment system ranked first on the basis of PEOU factors, while in specific terms, cash payment system ranked first on the crucial factors of ease of use and clarity of operating payment systems, and cheque payment system ranked first on the factors of rigidity/inflexibility and ability to manipulate payment systems. The challenge of e-payment system management if it is to become the dominant payment system in Nigeria is to make it easy and convenient to use. The specific factors defining its operations in Nigeria within the context of PEOU should be addressed. 


\subsection{Recommendations}

For e-payment system to become the dominant payment system in Nigeria, the following measures are proffered:

\section{Cannibalization of Cash and Cheque Payment Systems by E-Payment System}

Reduce the demand and use of cash and cheque payment systems while growing the demand and use of e-payment system platforms.

\section{Adoption of Counter Marketing Strategies for Cash and Cheque Payment Systems}

Given the desire of the promoters of e-payment system to make it the dominant payment system, the demand for cash and cheque payment systems should be seen as being unwholesome, demanding the adoption of counter marketing measures to reduce such demand. This will strategically dissuade demand for cash and cheque system and consequently enhance the demand for e-payment system platforms.

\section{Adoption of Developmental Marketing Strategy for E-Payment System}

All new products require and rely on generating and sustaining primary demand. This will require effective promotional campaigns aimed at educating, informing, persuading and reminding present and potential users to try, accept and prefer e-payment system platforms. Prospects use systems that they are aware of, consider for use, choose and ultimately prefer. Enhancement of literacy level including becoming computer savvy will also facilitate the acceptance and preference of e-payment system in financial transactions in Nigeria.

\section{Simplification of E-Payment Platforms Application}

This is with a view to making e-payment easy for users to remember how to perform tasks using the payment system application platforms. The simpler the application of e-payment platforms, the easier it will be to use them. It will also reduce the mental effort required to use them and facilitate wider use even by the less educated.

\section{Provision of Incentives to induce switching to E-Payment Platforms}

Like all new systems, especially one that has many familiar and established alternatives, switching to the new one will require incentives to get users to transit from the old to the new. In this particular instance, about $5 \%$ discount on amount to be paid when e-payment is used will induce many to use it.

\section{Training Of Prospective Users on E-Payment Platforms Tools and Processes}

One-on-one training of prospective users of e-payment platforms will help in overcoming inertia, hesitation and resistance to change. This training should be championed by banks, merchants and other relevant bodies that interface with users, especially at the point of trial. Being taken through the use of e-payment platform tools and processes will facilitate trial and acceptance when the experience is positive.

\section{Ready Availability and Accessibility of E-Payment Platforms to Many}

For e-payment system to become the dominant payment system in Nigeria, its various platforms should be readily available and accessible in needed outlets in both urban and rural areas. The use and preference of epayment platforms will grow as they become available to all who need them.

\section{Development of Infrastructure to Make E-Payment Platforms to Work Seamlessly}

Adequate infrastructural facilities will minimize most of the challenges associated with e-payment platforms and ensure that e-payment system works to meet the financial transaction needs and requirements of users. The problems of network/service failure and unavailability of e-payment platform tools and facilities that characterize e-payment at present need to be addressed by government and organizations involved in making epayment work in Nigeria.

\section{Deployment of Customer Service}

Necessary human and institutional capacities need to be deployed at Interface Points to make epayment platforms user friendly and the experience a happy and satisfying one to users. 


\section{VI. limitations of the study and further research}

The major limitation of the study was the segment of the population studied. The class of respondents represented the educated elite. With a minimum educational qualification of a first degree, this is an extreme segment of Nigerian population. Given that the literacy rate in Nigeria is $61.3 \%$ [17], a segment as educated as this group cannot represent the reality of general Nigerian situation. Another extreme of the study sample is their level of employment which stood at $94.68 \%$. This is a far cry from the employment circumstances of the Nigerian population. The unemployment level in Nigeria stands at $23.90 \%$ [18].

Given the centrality of education, level of financial activity and employment status of people in determining their PU and PEOU of payment systems and the lopsidedness of the study sample in these three critical areas pose a limitation in drawing conclusions on the PEOU based ranking of payment systems in Nigeria. It is useful however studying this segment of the population as a basis for the articulation of targeted interventions that may be necessary in securing quick wins and building a critical mass of early adopters of epayment system that will serve as a platform for subsequent spreading of the need for the wider acceptance of the payment system by the general population. The choice of the sample studied was therefore deliberate and strategic. It nonetheless necessitates further studies to assess how other less educated and less financially active Nigerians rank payment systems in Nigeria. Other social issues like religion and tribe can also be explored in establishing the factors that define the ranking of payment systems in Nigeria.

\section{References}

[1] J. Ovia, Enhancing the efficiency of the Nigerian payments system, CBN, Volume 29no 1, 2005.

[2] Financial Derivatives Company Limited (FDCL), Cash-less POS survey-Lagos from cash to card, November, 2012.

[3] C.I. Okeke, Determination of the core benefits and challenges associated with e-payment system in Nigeria, International Journal of Emerging Knowledge, 2014, Vol.1 (12).204-218.

[4] L.J. Mester, The changing nature of the payments system: should new players mean new rules? Bus. Rev. (Fed. Res. Bank of Philadelphia), March/April, 2000.

[5] E. Eze, A critical examination of information technology strategic variables from developing countries perspective: the case of banking industry, 2001. Http//Www.Haworthpress.Com/Store/Articleabstract.Asp?Sid=Rx79x33231v780n8wru

[6] A. Ezeoha, Regulating internet banking in Nigeria: some success prescriptions part 2. Journal of Internet Banking and Commerce, Vol.11, No 1. 2006.Http://Www.Arraydev.Com/Commerce/Jibc/

[7] E-Payment Providers Association of Nigeria (E-PPAN), Cashless Lagos Success Monitoring, 2013.

[8] F.D. Davis, "Perceived Usefulness, Perceived Ease of Use and User Acceptance of It". MIS Quarterly 1989.

[9] F.D. Davis, R.P. Bagozzi, and P.R. P.R. Warshaw, "User acceptance of computer technology: A comparison of two theoretical models." Management Science, 1989

[10] P. Legris, J. Ingham, and P. Collerette, Why do people use information technology? A critical review of the Technology Acceptance Model. Information \& Management, 40, 191-204, 2003.

[11] M. Dimock, The keyword cannibalization survival guide, Retrieved (November 11, 2013).http://www.imarketsolution.com/blog/content-strategy/

[12] M.F Goodchild, Ilacs: A Location Allocation Model For Retail Site Selection, Journal of Retailing (60): 84-100, (1984). Doi: 10.1111/J.1538-4632.1989.tb00900.X

[13] Http://En.Wikipedia.Org/W/Index.Php?Title=Cannibalization_(Marketing)\&Oldid=591583228.

[14] J. Useem, Fine young cannibal. Fortune, (September 6, 1999).

[15] K. Charmaz, Grounded theory: objectivist and constructivist methods, in N.K. Denzin and Y.S. Lincoln (Eds.), Strategies of qualitative inquiry, ( $2^{\text {nd }}$ Ed.), (Thousand Oaks, CA; Sage, 2003).

[16] K. Henwood, and N. Pidgeon, Qualitative research and psychological theorizing, in Hammersley, Martyn (Ed.) social research: philosophy, politics and practice (London: Sage, 1993).

[17] United Nations Human Development Report, World map indicating literacy by country, (UNHDR, 2014).

[18] National Bureau of Statistics, Unemployment rate in Nigeria, (NBS. 2014),

\section{About The Author}

Dr C. I. Okeke holds a PhD in Marketing from Abia State University, Uturu, Abia State, Nigeria. He is an Associate Professor and Head of PhD and Masters Programmes Unit in National Open University of Nigeria, Lagos. He was previously a Director of Research and Consultancy in the Centre for Management Development, Lagos and Director General of Abuja Graduate School, Abuja, Nigeria. 